\title{
Digestibility and Elemental Assimilation in Cotton Rats*
}

\author{
Donald W. KAUFMAN, Michael J. O'FARRELL, Glennis A. KAUFMAN \\ \& Susan E. FULLER
}

\begin{abstract}
Kaufman D. W., O'Farrell M. J., Kaufman G. A. \& Fuller S. E., 1976: Digestibility and elemental assimilation in cotton rats. Acta theriol, 21, 9: $147-156$. [With 3 Tables].

Digestibility $(82 \%)$ was measured directly for 10 cotton rats in the laboratory. Subsequently, digestibility was estimated using the ratio of ash in food and feces as well as the ratio technique with 15 specific elements. Digestibility estimates were all too low, therefore, the fecal ash values were corrected relative to a digestibility of $82 \%$. Using the same correction factor with the modified ash ratio technique, digestibility was estimated to be $78 \%$ under field conditions. Digestibility values for the 23 field-caught cotton rats were all too low using the ratio technique for the 15 specific elements, however, the $\mathrm{Ba}$ estimate was $76 \%$. Assimilation of each element under both laboratory and field conditions were estimated from digestibility values and the elemental concentration data for stomach contents and feces. Problems with estimating elemental assimilation are discussed relative to the specific elements examined.

Dept. Biol. Sci, State Univ. N. Y., Binghampton, Dept. Biol. Sci., Univ. Nevada, Las Vegas, Nevada; Savannah River Ecol, Lab., Drawer E, Aiken, South Carol.].
\end{abstract}

\section{INTRODUCTION}

Ecological studies of energy and nutrient flow through a population require the estimation of assimilation efficiencies for energy and nutrients. Estimation of energy assimilated and biomass digested in field populations has been attempted using a variety of techniques (see review by $\mathrm{Golle} y, 1967)$. These include ratio techniques using indigestible indicators in the food, e.g., cellulose, chromogen and silica (Van D y n e \& Meyer, 1964; Short \& R emmenga, 1965) or applied to the food, e.g., chromium-51 (M a u t z \& P etrid es, 1967; M a u tz, 1971). Major problems arise when the indicator is partly digestible, low in concentration or extremely variable in concentration in the foods (Van Dyne \& Meyer, 1964). Johnson \& Maxell (1966) suggested using the ratio inorganic ash in food and feces to estimate digestibility in field-caught pikas. Their technique incorrectly assumed that the animals were in mineral balance and that there was effectively no loss of ash from the feces. The technique was later modified by Johns on

* Research was supported by contract AT(38-1)-819 between the U.S. Atomic Energy Commission and the University of Georgia. 
$\&$ Groepper (1970) so that the proportion of ash assimilated under laboratory conditions was used to correct ash analyses of field animals. Field digestibility was then estimated from the ratio of ash in food to the corrected fecal ash value (J o hns on \& Groepper, 1970; S oholt, 1973).

Studies of nutrient flow through populations require estimates of ingestion, egestion and assimilation rates of specific elements as well as assimilation of total biomass. Although elemental concentrations and standing crops of small mammals have been studied (B eyers et al., 1971; Nabholz, 1973; Sella, 1973; Gentry et al., 1975), little is known concerning elemental flow through the small mammal component of ecosystems. Considerable effort has been devoted to the study of elemental absorption and excretion in mammals in the laboratory (e.g., see review by Wiseman, 1964); however, most of these techniques are not feasible for use in the field. Bries e (1973) estimated egestion for a population of cotton rats as the difference between the amount of an element ingested and the amount used for growth and reproduction. But again this approach is not very satisfactory for estimating elemental assimilation in field populations.

We measured digestibility directly for cotton rats (Sigmodon hispidus) in the laboratory and then calculated the correction factor for the modified ash ratio technique. We then examined digestibility estimates calculated from the concentration of 15 individual elements in the stomach contents and feces. Ash and elemental concentration of stomach contents and feces were also used to estimate digestibility for field-caught cotton rats. Finally, we present a technique for estimating elemental assimilation in animals from elemental concentration in food and feces when digestibility is known.

\section{METHODS AND MATERIALS}

\section{Laboratory Study}

Rats were live-trapped on the Savannah River Plant and maintained under laboratory conditions for over one month. Measurements of ingestion and egestion were made over a 4-day period for 10 cotton rats maintained in metabolic cages. Rats were kept in the metabolic cages for 1 week prior to these measurements. Water was provided ad lib. Purina lab chow dried to constant weight was placed in the cage daily. Food remaining after each 24 -hour period was removed, placed in a drying oven $\left(25^{\circ} \mathrm{C}\right)$ and brought to constant weight. Feces were collected daily and oven-dried until constant weight was achieved. Digestibility of food was calculated from the amount of ingesta and egesta over the 4-day period for each of the 10 animals.

Laboratory animals were sacrificed and weighed $(\bar{x}=99.7 \mathrm{~g}, 2 \mathrm{SE}=13.5 \mathrm{~g})$. Stomach contents and fecal pellets from the large intestine were removed and weighed. Ingesta and egesta were freeze dried to a constant weight and then pulverized 
for use in ash and elemental analyses. Samples were ashed at $450^{\circ} \mathrm{C}$ for 4 hours. Concentrations of all elements except $\mathrm{N}$ were analyzed on a Jarrell-Ash direct reading 1.5-meter emission spectrograph. Procedures were similar to that of $\mathrm{K}$ a u f m a n \& K a u f man (1975). Nitrogen was determined by the micro-Kjeldahl technique (Association Official Agricultural Chemists, 1960).

\section{Field Study}

Cotton rats were snap-trapped on the Savannah River Plant during November, 1973. Animals $(\mathrm{N}=23)$ were weighed $(\bar{x}=99.9 \mathrm{~g}, 2 \mathrm{SE}=17.0 \mathrm{~g})$ and contents of stomach and large intestine removed. Samples were processed in the same manner as in the laboratory phase.

\section{Mathematical Analyses}

Digestibility (D) was calculated from

$$
D=\left[1-\frac{(1 / y)-1}{\left(1 / y_{0}\right)-1}\right] \times 100
$$

where $y_{0}$ is the proportion of ash in the stomach contents and $y$ is the proportion of ash in the feces (J o hns on \& M a x ell, 1966). Later, $y$ included a correction to account for loss of ash in the urine ( $\mathrm{J}$ ohnson \& Groepper, 1970). The correction factor was determined in the laboratory and applied to the field assuming that the proportion of ash assimilated would remain the same. Digestibility discussed in this paper will always refer to the ash-free portion of the food.

We cannot use Johnson \& Maxell's (1966) equation with the elemental concentrations because the equation would give the element-free digestibility rather than the ash-free digestibility. The appropriate equation for digestibility from elemental concentration data when the element is unassimilated is

$$
D=\left[1-\frac{I_{\mathrm{i}} / 1-y_{0}}{E_{\mathrm{i}} / 1-y}\right] \times 100
$$

where $I_{i}$ and $E_{i}$ are the concentrations $i$ in the ingesta and egesta, respectively and $y_{0}$ and $y$ are ash concentrations.

In egesta, the observed ratio $\left(E_{i \bullet \text { obs }}\right)$ of an element to ash-free material is $E_{i} / 1-y$ whereas the expected ratio $\left(E_{i \cdot \exp }\right)$ without elemental assimilation is $I_{i} /\left(1-y_{0}\right)(1-D / 100)$. Assimilation for element $i\left(A E_{i} \%\right)$ can then be calculated from

$$
A E_{i} \%=\left[\frac{E_{i \cdot \exp }-F_{i \cdot o b s}}{E_{i \cdot \exp }}\right] \times 100
$$

\section{RESULTS}

Cotton rats consumed $8.2 \mathrm{~g}(2 \mathrm{SE}=1.8)$ of lab chow (dry weight) with an average digestibility of $82.4 \%(2 \mathrm{SE}=1.9)$ calculated from feeding experiments. The estimate of digestibility (Eq. 1) from ash concentrations in stomach contents and feces (Table 1) was only 62.0. Considerable ash 
Table 1

Concentrations ( $\pm 2 \mathrm{SE}$ ) of 15 elements in the ingesta $\left(I_{i}\right)$ and egesta $\left(E_{i}\right)$ for both laboratory and field cotton rats.

\begin{tabular}{|c|c|c|c|c|}
\hline \multirow{2}{*}{ Element } & \multicolumn{2}{|c|}{ Laboratory } & \multicolumn{2}{|c|}{ Field } \\
\hline & $I_{i}$ & $E_{i}$ & $I_{i}$ & $E_{i}$ \\
\hline $\mathrm{Al}^{2}$ & $0.04 \pm 0.02$ & $0.07 \pm 0.01$ & $0.17 \pm 0.09$ & $0.44 \pm 0.16$ \\
\hline $\mathrm{Ash}^{2}$ & $9.74 \pm 0.99$ & $22.13 \pm 2.43$ & $8.54 \pm 3.30$ & $16.46 \pm 5.32$ \\
\hline$B^{3}$ & $12.3 \pm 5.2$ & $9.7 \pm 3.3$ & $13.7 \pm 2.3$ & $16.4 \pm 2.0$ \\
\hline $\mathrm{Ba}^{3}$ & $10.0 \pm 9.5$ & $32.0 \pm 13.3$ & $35.4 \pm 10.8$ & $134.2 \pm 27.7$ \\
\hline $\mathrm{Ca}^{2}$ & $1.81 \pm 0.75$ & $4.98 \pm 1.18$ & $0.26 \pm 0.07$ & $0.52 \pm 0.09$ \\
\hline $\mathrm{Cu}^{3}$ & $24.7 \pm 12.1$ & $40.3 \pm 7.9$ & $17.2 \pm 5.4$ & $30.6 \pm 6.4$ \\
\hline $\mathrm{Fe}^{2}$ & $0.10 \pm 0.05$ & $0.21 \pm 0.04$ & $0.07 \pm 0.03$ & $0.16 \pm 0.04$ \\
\hline $\mathrm{K}^{2}$ & $0.95 \pm 0.53$ & $0.70 \pm 0.21$ & $1.14 \pm 0.15$ & $1.31 \pm 0.13$ \\
\hline Mg2 & $0.23 \pm 0.10$ & $0.58 \pm 0.21$ & $0.14 \pm 0.03$ & $0.22 \pm 0.03$ \\
\hline $\mathrm{Mn}^{3}$ & $116 \pm 63$ & $294 \pm 73$ & $112 \pm 25$ & $380 \pm 71$ \\
\hline $\mathrm{Mo}^{3}$ & $2.4 \pm 0.6$ & $3.9 \pm 0.6$ & $6.1 \pm 2.6$ & $15.3 \pm 4.8$ \\
\hline $\mathrm{N}^{2}$ & $4.58 \pm 0.15$ & $4.10^{1}$ & $3.43 \pm 0.41$ & $3.12 \pm 0.34$ \\
\hline $\mathrm{Na}^{2}$ & $0.34 \pm 0.23$ & $0.28 \pm 0.14$ & $0.24 \pm 0.05$ & $0.31 \pm 0.04$ \\
\hline $\mathrm{P}^{2}$ & $1.68 \pm 0.82$ & $4.42 \pm 1.23$ & $0.44 \pm 0.06$ & $0.73 \pm 0.07$ \\
\hline $\mathrm{Sr}^{3}$ & $35.0 \pm 18.2$ & $90.0 \pm 20.1$ & $18.3 \pm 5.3$ & $50.8 \pm 8.0$ \\
\hline $\mathrm{Zn}^{3}$ & $124 \pm 65$ & $383 \pm 175$ & $55 \pm 10$ & $151 \pm 25$ \\
\hline
\end{tabular}

${ }^{1} E_{i}$ was available for only one rat. ${ }^{2}$ Concentration given in pph. 3 Concentration given in $\mathrm{ppm}$.

Table 2

Ash-free digestibility coefficients $(D)$ estimated from concentrations of 15 elements in stomach contents and feces for laboratory and field-caught cotton rats.

Elements are ranked in order of descending digestibility for the laboratory group; relative ranking for field animals are given in parentheses. $A E_{i} \%$ calculated from $D=82.4 \%$ in laboratory and $78 \%$ in field.

\begin{tabular}{|c|c|c|c|c|c|}
\hline \multirow{2}{*}{ Element } & \multicolumn{2}{|c|}{ Laboratory } & \multicolumn{3}{|c|}{ Field } \\
\hline & $\mathrm{D}$ & $A E_{i} \%$ & $\mathrm{D}$ & $A E_{i} \%$ & Rank \\
\hline $\mathrm{Ba}$ & 73 & 35 & 76 & 9 & ( 1$)$ \\
\hline $\mathrm{Zn}$ & 72 & 37 & 67 & 34 & ( 3$)$ \\
\hline $\mathrm{Ca}$ & 69 & 44 & 54 & 52 & ( 8$)$ \\
\hline $\mathrm{P}$ & 67 & 46 & 45 & 60 & (10) \\
\hline $\mathrm{Mg}$ & 66 & 49 & 42 & 62 & (11) \\
\hline $\mathrm{Sr}$ & 66 & 48 & 67 & 33 & ( 3 ) \\
\hline $\mathrm{Mn}$ & 66 & 48 & 73 & 18 & ( 2) \\
\hline $\mathrm{Fe}$ & 59 & 57 & 60 & 45 & ( 7$)$ \\
\hline $\mathrm{Al}$ & 51 & 64 & 65 & 38 & ( 5$)$ \\
\hline $\mathrm{Cu}$ & 47 & 67 & 49 & 57 & ( 9 ) \\
\hline Mo & 47 & 67 & 64 & 40 & ( 6$)$ \\
\hline $\mathrm{N}$ & 4 & 82 & 0 & 78 & (15) \\
\hline $\mathrm{Na}$ & -5 & 83 & 29 & 69 & (12) \\
\hline B & -9 & 84 & 24 & 71 & (13) \\
\hline $\mathrm{K}$ & -17 & 85 & 21 & 72 & (14) \\
\hline
\end{tabular}


was assimilated, $53.4 \%$ as calculated using Eq. 3, resulting in a correction factor of 2.15. Using the corrected ash concentration in feces, the average estimate of digestibility in field-caught animals was $78.0 \%$ (Eq. 1) (the non-corrected ash estimate of digestibility was $53 \%$ ).

Estimates of digestibility (Eq. 2) in the laboratory ranged from -17 to $73 \%$ (Table 2) using elemental concentrations in ingesta and egesta (Table 1). Ash and elemental concentrations of ingesta and egesta for field-caught cotton rats differed considerably from concentrations in the laboratory (Table 1). Digestibility estimates for field-caught animals were also different from estimates for laboratory animals (Table 2).

Table 3

Amounts of elements assimilated per gram food ingested and per $100 \mathrm{~g}$ rat per day using laboratory and field-caught cotton rats.

\begin{tabular}{lrrrrr}
\hline & \multicolumn{2}{c}{ Per Gram Food } & & \multicolumn{2}{c}{ Per 100 g Rat Per Day ${ }^{1}$} \\
\cline { 2 - 3 } & Laboratory & Field & & Laboratory & Field \\
\hline $\mathrm{Al}^{2}$ & 0.3 & 0.6 & & 2.5 & 4.3 \\
$\mathrm{~B}^{3}$ & 10.3 & 9.7 & & 84.5 & 65.2 \\
$\mathrm{Ba}^{3}$ & 3.5 & 3.2 & & 28.7 & 21.3 \\
$\mathrm{Ca}^{2}$ & 8.0 & 1.4 & & 66 & 9 \\
$\mathrm{Cu}^{3}$ & 16.5 & 9.8 & & 135.3 & 65.7 \\
$\mathrm{Fe}^{2}$ & 0.6 & 0.3 & & 4.9 & 2.1 \\
$\mathrm{~K}^{2}$ & 8.1 & 8.2 & & 66 & 55 \\
$\mathrm{Mg}^{2}$ & 1.1 & 0.9 & & 9.0 & 5.8 \\
$\mathrm{Mn}^{3}$ & 56 & 20 & & 459 & 135 \\
$\mathrm{Mo}^{3}$ & 1.6 & 2.4 & & 13.1 & 16.3 \\
$\mathrm{~N}^{2}$ & 37.6 & 26.8 & & 308 & 179 \\
$\mathrm{Na}^{2}$ & 2.8 & 1.7 & & 23 & 11 \\
$\mathrm{P}^{2}$ & 7.7 & 2.6 & & 63 & 18 \\
$\mathrm{Sr}^{6}$ & 16.8 & 6.0 & & 137.8 & 40.5 \\
$\mathrm{Zn}^{3}$ & 46 & 18.7 & 377 & 125.3 \\
\hline
\end{tabular}

1 Food ingested per day was $8.2 \mathrm{~g}$ for laboratory animals (this study) and $6.7 \mathrm{~g}$ for field animals ( $\mathrm{r}$ i e s e, 1973). ${ }^{2}$ Amounts given in $\mathrm{mg}$. ${ }^{3}$ Amounts given in $\mu \mathrm{g}$.

Elemental assimilation efficiency $\left(A E_{i} \%\right)$ relative to a digestibility of $82 \%$, ranged from 35 to $85 \%$ in the laboratory (Eq. 3; Table 2). The four elements with the greatest assimilation were $\mathrm{K}, \mathrm{B}, \mathrm{Na}$ and $\mathrm{N}$. In the field, elemental assimilation efficiency ranged from 9 to $78 \%$ (Table 2) with the field digestibility of $78 \%$. Although values are lower and in a different sequence for the field study, N, K, B and $\mathrm{Na}$ still had the greatest assimilation efficiencies.

The amounts of elements assimilated per gram of food eaten and amounts of elements assimilated per $100 \mathrm{~g}$ cotton rat per day are summarized in Table 3 for both laboratory and field studies. 


\section{DISCUSSION}

\section{Digestibility}

Our digestibility coefficient for the cotton rat in the laboratory $(82 \%)$ was similar to most values (range $71-83 \%$ ) reported for other rodents feeding on rat chow ( $\mathrm{J}$ ohnson \& Groepper, 1970). The estimate of the digestibility from ash concentrations was only $62 \%$ since $53 \%$ of the ash in food was assimilated by the cotton rats under laboratory conditions. Assuming similar ash assimilation in the field, amounts of ash in feces of field animals were corrected using a factor of 2.15. Estimated digestibility in the field using the modified ash-tracer method was $78 \%$ which is similar to values for other foliage-eating rodents $(72-93 \%$; 7 of the 8 values between 72 and $82 \%$; J o h n s on \& G r o e ppe r, 1970).

Estimates of digestibility using each of the elements were lower than the true value in the laboratory. Considerable variability among the 15 estimates was found with the highest value of $73 \%$ for $\mathrm{Ba}$ (Table 2). Estimates of digestibility for field-caught animals also showed considerable variability across the 15 elements (Table 2). Again, $\mathrm{Ba}$ gave the highest estimate $(76 \%)$ and was similar to the estimate from the modified ash-tracer method. The estimate of digestibility from Mn was also quite high $(73 \%)$.

Examination of values for laboratory and field (Table 2) suggests that a few elements (e.g., $\mathrm{Ba}, \mathrm{Zn}, \mathrm{Mn}$ and $\mathrm{Sr}$ ) may prove useful as estimators of digestibility. The potential of these elements is due to the fact that although they are assimilated to varying degrees, most excretion is through the intestine rather than in the urine (B o w e $n, 1966$; see discussion below). Therefore, when the animal is in mineral balance, elemental concentrations in stomach contents and feces may be reasonable estimators of digestibility. Of these, Ba which is non-essential is the most promising, especially when the concentration of $\mathrm{Ba}$ in the food is relatively high as under field conditions (Table 1). More work remains to be done on individual elements since even slight assimilation and loss in urine would decrease the effectiveness of the use of an element as a tracer. However, utilization of elements as estimators may be improved by the development of correction factors in much the same manner as was done for ash ( $\mathrm{J}$ ohns on \& G r o e p p e r, 1970).

\section{Elemental Assimilation}

Considerable information is available from laboratory studies on the assimilation of elements by mammals (W is e m a $n, 1964$ ); however, few data are available for mammals under natural conditions. Our approach 
has been to estimate fecal excretion and, therefore, to be able to make minimal estimates of the assimilation of elements for field-caught animals. These estimates of assimilation are minimal since the values for fecal excretion include non-assimilated molecules plus compounds that have been secreted back into the intestine. In addition, the difference between the true $A E_{i} \%$ and our estimate of $A E_{i} \%$ would be almost impossible to determine under field conditions and in fact would vary spatially and temporally due to the large number of factors that affect elemental absorption (W i s e m a n, 1964; $\mathrm{B}$ ow e $\mathrm{n}, 1966$ ).

Bowen (1966) presented a summary of elemental metabolism in humans using data given in Spector (1956). Bowen grouped the elements into three classes with respect to their absorption and for the elements we examined the classification is as follows:

Class 1: $>70 \%$ absorbed across the gut wall

Excretion largely in the urine.

Class 2: $5-70 \%$ absorbed across the gut wall Excretion $\geqslant 10 \%$ in the urine.

Anions: B, Mo, N Cations: $\mathrm{K}, \mathrm{Na}$

Anions: P

Excretion largely in the feces

Cations: $\mathrm{Cu}, \mathrm{Mg}$

Cations: $\mathrm{Ba}, \mathrm{Ca}, \mathrm{Sr}$

Class 3: $<5 \%$ absorbed across the gut wall

Excretion largely in the feces.

Cations: $\mathrm{Al}, \mathrm{Fe}, \mathrm{Mn}, \mathrm{Zn}$

Assuming that elemental metabolism of small mammals is similar to that of humans, we can relate our findings to this information. Therefore, we would expect our assimilation efficiencies to be high for $\mathrm{B}, \mathrm{K}, \mathrm{Na}$, Mo and $N$ which is true $\left(A E_{i}{ }^{0} \%=85(\mathrm{~K}), 84(\mathrm{~B}), 83(\mathrm{Na}), 82(\mathrm{~N})\right.$ and $67(\mathrm{Mo})$. Assimilation efficiences for these Class 1 elements should also approach the true value of $A E_{i} \%$ and be very useful in field studies. Assimilation efficiency values for $\mathrm{P}, \mathrm{Cu}$ and $\mathrm{Mg}$ (Class 2 elements) may or may not approach the true value of $A E_{i} \%$ since as little as $10 \%$ is excreted in the urine. The other seven elements $(\mathrm{Ba}, \mathrm{Ca}$ and $\mathrm{Sr}$ of Class 2 and $\mathrm{Al}, \mathrm{Fe}, \mathrm{Mn}$ and $\mathrm{Zn}$ of Class 3 ) are excreted primarily in the feces and because of this, $A E_{i} \%$ may be much too low.

Assimilation efficiency for any element may vary under different diets due to differences in concentration of the element in various foods. Therefore, we compared field and laboratory estimates of elemental assimilation per day for a $100 \mathrm{~g}$ rat (Table 3). Several elements were assimilated in similar amounts in both field and laboratory animals whereas others were quite different (Table 3). The variation may be related to factors such as differences in growth and water intake between laboratory and field. In addition, differences in molecular forms of elements may have 
existed between lab chow and the natural diet of the cotton rat thus causing variation in assimilation.

Our approach to estimating elemental assimilation in the field is quite crude when compared to complex laboratory experiments. However, these estimates along with estimates of the amounts of elements used in growth and reproduction can be used to further dissect elemental flow in a population. Even though the assimilation efficiencies are minimal, the allocation of elements to maintenance, growth and reproduction relative to our $A E_{i} \%$ should be useful in examining inter-and intraspecific differences in elemental flow.

Acknowledgements: We thank J. G. Wiener for reviewing an earlier draft of this manuscript.

Reprint requests should be sent to Librarian, Savannah River Ecology Laboratory, Drawer E, Aiken, South Carolina 29801 U.S.A.)

\section{REFERENCES}

1. Association Official Agricultural Chemists, 1960: Methods of analysis. 1-832 Washington, D. C.

2. Beyers R. J., Smith M. H., Gentry J. B. \& Ramsey L. L., 1971: Standing crops of elements and atomic ratios in a small mammal community. Acta theriol., 16: 203-211.

3. Bowen H. J. M., 1966: Trace elements in biochemistry. Academic Press: 1-241. London.

4. Briese L. A., 1973: Variations in elemental composition and cycling in the cotton rat, Sigmodon hispidus. M. S. Thesis, Univ, of Georgia, Athens. $71 \mathrm{p}$.

5. Gentry J. B., Briese L. A., Kaufman D. W., Smith M. H. \& Wiener J. G, 1974: Elemental flow and standing crops for small mammal populations. [In: "Small Mammals: Their Productivity and Population Dynamics", Eds. Golley, F. B., Petrusewicz, K., \& Ryszkowski, L.]. Cambridge Univ. Press: 205-221. London.

6. Golley F. B., 1967: Methods of measuring secondary productivity in terrestrial vertebrate populations. [In: "Secondary Productivity of Terrestrial Ecosystems (Principles and Methods)«, Ed. Petrusewicz, K.]. 1: 99-119. Polish Acad. Sci. Warsaw.

7. Johnson D. R. \& Groepper K. L., 1970: Bioenergetics of North Plains rodents. Amer. Midl. Nat., 84: 537-548.

8. Johns on D. R. \& M axell M. H., 1966: Energy dynamics of Colorado pikas. Ecology, 47: 1059-1061.

9. Kaufman G. A. \& Kaufman D. W., 1975: Effects of age, sex and pelage phenotype on elemental composition of the old-field mouse (Peromyscus polionotus). [In: "Mineral Cycling in Southeastern Ecosystems«, Eds. Howell, F. G., Gentry, J. B. \& Smith, M. H.]. AEC Symposium Series : 518-527.

10. Mautz W. W., 1971: Comparison of the ${ }^{51} \mathrm{CrCl}_{3}$ ratio and total collection techniques in digestibility studies with a wild ruminant, the white-tailed deer. J. Anim. Sci., 32*999-1002.

11. Mautz W. W. \& Petrides G. A., 1967: The usefulness of chromium-51 in digestive studies of the white-tailed deer. Proc. N. Amer. Wildl. Conf., 32: 420 -429 . 
12. Nabholz J. V., 1973: Small mammals and mineral cycling on three Coweeta watersheds. M, S. Thesis, Univ. of Georgia, Athens. 87 p.

13. Sella L. D., 1973: Trace elements in the cotton rat, Sigmodon hispidus, on the Piedmont of Georgia. M. S. Thesis, Univ. of Georgia, Athens, 52 p.

14. Short H. L. \& Remmenga E. E., 1965: Use of fecal cellulose to estimate plant tissue eaten by deer. J. Range Manage, 18: 139-144.

15. Soholt L. F., 1973: Consumption of primary production by a population of kangaroo rats (Dipodomys merriami) in the Mojave Desert. Ecol. Monogr., 43: $357-376$.

16. Spe ctor W. S., 1956: Handbook of biological data. W. B. Saunders Co., 1-584. Philadelphia.

17. Van Dyne G. M. \& Me y e r J. H., 1964: A method for measurement of forage intake of grazing livestock using microdigestion techniques. J. Range Manage, 17: $204-208$.

18. W is eman G., 1964: Absorption from the intestine. Academic Press: 1-564 London.

Accepted, April 10, 1975.

Donald W. KAUFMAN, Michael J. O'FARRELL, Glennis A. KAUFMAN i Susan E. FULLER

\section{STRAWNOSĆ I ASYMILACJA PIERWIASTKÓW U BAWEENIAKA}

\section{Streszczenie}

Strawność mierzono w warunkach laboratoryjnych u 10 bawełniaków (Sigmodon hispidus). Następnie zbadano u tych samych osobników koncentrację popiołu i 15 pierwiastków w treści żołądka i w kale (Tabela 1). Dodatkowo zmierzono koncentrację popiołu i pierwiastków w treści żołądka i kale 23 bawełniaków złowionych w terenie (Tabela 1).

Współczynnik strawności w laboratorium wynosił $82 \%$ a obliczony przy użyciu popiołu jako wskaźnika był równy $62 \%$ (równanie 1). Niska strawność uzyskana ostatnim sposobem była powodowana tym, że część pierwiastków zawartych w popiole była asymilowana i dlatego wprowadzono poprawkę $(2,15)$ na zniwelowanie tej straty. Współczynnik strawności oznaczony na podstawie pierwiastków (równanie 2) był także zbyt niski (Tabela 2).

W terenie współczynnik strawności wynosi $78 \%$ co oznaczono przy użyciu zmodyfikowanej metody wskaźnikowej z zastosowaniem popiołu (poprawka 2,15). Wskaźniki strawności oznaczane przy użyciu pierwiastków wszystkie były niższe niż $78 \%$ jakkolwiek oznaczenia za pomocą $\mathrm{Ba}(76 \%)$ i $\mathrm{Mn}(73 \%)$ były bliskie ustalonej wartości. Niektóre z pierwiastków (Ba, $\mathrm{Zn}, \mathrm{Mn}$ i $\mathrm{Sr}$ ) mogą okazać się użyteczne jako wskaźniki strawności, po zastosowaniu poprawki takiej jak została użyta w przypadku popiołu.

Dokonano także obliczeń tempa asymilacji 15 różnych pierwiastków i to zarówno w laboratorium jak i w warunkach terenowych, posługując się przy tym danymi o ich zawartości w treści żołądka i w kale (równanie 3). Dane o gospodarce mineralnej skalkulowano dla bawełniaka o ciężarze $100 \mathrm{~g}$, na podstawie dobowego po- 
brania pokarmu i tempa asymilacji pierwiastków (Tabela 2). Tempo asymilacji dla niektórych pierwiastków jest inne w terenie a inne w laboratorium, co częściowo powodowane jest różną koncentracją substancji mineralnych w diecie laboratoryjnej i w pokarmie naturalnym. Poza tym zmienia się też poziom asymilacji dobowej co dowodzi, że zarówno wzrost jak i pobranie wody mają także wpływ na wielkość asymilacji. Dyskutowano także sprawę dokładności oznaczeń asymilacji substancji mineralnych, gdyż zależy to nie tylko od wieku zwierzęcia i jego stanu fizjologicznego, ale także i retencji tych substancji. 